UDC332.33

\title{
THEORETICAL FEATURES OF THE FORMATION OF THE MECHANISM OF REGULATION OF LAND RELATIONS
}

Movchan S.I., PhD in Technology

E-mail: sergey.movchan@tsatu.edu.ua

Yakunicheva A.Yu., PhD in Economics

E-mail: anastasiia.yakunicheva@tsatu.edu.ua

Lezhenkin I.O., PhD in Technology

E-mail: legenkini@ukr.net

Kolomiiets S.M. PhD in Technology

E-mail:ksm_63@ukr.net

Dmytro Motornyi Tavria State Agrotechnological University

The content of the economic category "land relations" is an important element; the factors that determine the peculiarities of land relations in agriculture and establish the principles of their regulation are studied.

The author describes a model of the mechanism for regulating land relations, which is presented in the form of a set of structural and functional parts (a system of economic, legal, management and environmental regulators and subsystems of regulatory support), which allow using special methods and tools to influence the subjects of land relations within the framework of the state land policy implementation in order to achieve the goals of state land management; the inconsistency of the situation is revealed, which is associated with the large-scale encumbrances of land involved in the agricultural sector, and the simultaneous absence of easements. The described problem arose both due to the unlimited ownership of the encumbered land plots, and due to the rarity of their installation; We have identified the specificity of land easements in the agricultural sector, which in turn confirms that most of them arose in the conditions of the predominance of state ownership of land, when encumbrance agreements were not drawn up and in the absence of activity on the part of the state to form mechanisms for recognizing land encumbrances in the legislative 
field; in the context of the establishment of land easements and the introduction of obligatory easement payments; in the absence of uniform methods for determining proportionate compensation for encumbrances on productive lands; also due to illconceived mechanisms for reinvesting funds received by land owners in the form of servitude payments in the reproduction of land resources; in the absence of mechanisms for obtaining easement payments for encumbrance of land plots, the ownership of which is not delimited.

Key words: land relations, land resources, regulation mechanism, land servitude, servitude

Formulation of the problem. The development of the agricultural sector of the economy is largely determined by the quality of the land relations system, their adequacy to social needs, the ability to ensure the required level of efficiency in land management and reproduction of productive lands. Insufficiently high level of land tenure and land use efficiency, unreasonable land payments, an unclaimed large number of land plots, where the processes of degradation of productive lands continue, indicate the presence of certain problems in the field of agricultural land management, contradictions in the land relations system and incomplete processes. their regulation.

Analysis of recent research and publications. The development of the agricultural sector of the economy is largely determined by the quality of the land relations system, their adequacy to social needs, the ability to ensure the required level of efficiency in land management and reproduction of productive lands. Insufficiently high level of land tenure and land use efficiency, unreasonable land payments, an unclaimed large number of land plots, where the processes of degradation of productive lands continue, indicate the presence of certain problems in the field of agricultural land management, contradictions in the land relations system and incomplete processes their regulation.

In the broadest sense, land relations are a system of social relations that arise between the subjects of land law on the possession, disposal and use of land and 
management of land resources. Land relations are traditionally considered as a specific sphere of manifestation of public interests, as a form of reflection objectively arise and develop significantly significant connections and dependencies, as a natural element of the system of social reproduction. Land relations reflect a system of deep basic interests of all subjects of these relations, characterized by a high level of heterogeneity and contradictions.

At the present level of social development, the state plays the role of a natural regulator of the entire system of social relations, including land relations $[1,3,11,13]$.

The purpose of the article is the formation of the mechanism of land relations in the implementation of land policy of the state to achieve the goals of state management of land relations.

Materials and methods of research. To obtain the planned results, which will correspond to the name and purpose of the study, the scientific article will use the generally accepted methods of scientific knowledge, which include the method of analysis and the method of comparative analysis. In particular, the method of analysis will allow us to identify the components and their relationships used in the formation of the mechanism for regulating land relations.

Results of research and discussion. The peculiarity of land relations and the system of their regulation is determined primarily by the specifics of land as an object of these relations, due to: first, the versatility of land and its indispensability for agriculture; secondly, the direct or indirect participation of literally every member of society in relations concerning the possession, disposal, use of land and economic benefits derived from its production use, thirdly, the specific form of income of landowners arising in the form of land rent, and mechanisms for its withdrawal and redistribution; fourth, significant differentiation of lands by their quality; fifth, the peculiarities of the reproduction of productive lands as a factor of agricultural production; sixth, its limitations and absolute immobility; seventh, the specificity of land as a commodity and the organization of land turnover.

State regulation of land relations should ensure the creation of conditions for rational and efficient land use, protection of property rights, transparency of land 
transactions, optimization of a land management system. Regulation of land relations is traditionally considered as an element of the system of state management of land resources [10].

The mechanism of regulation of land relations is a set of structural and functional elements (regulators and subsystems that provide it), which allow using special methods and tools to influence the subjects of land relations in the implementation of land policy and achieve the goals of state management of land relations.

The model of the proposed mechanism for regulating land relations is shown in Fig. 1.

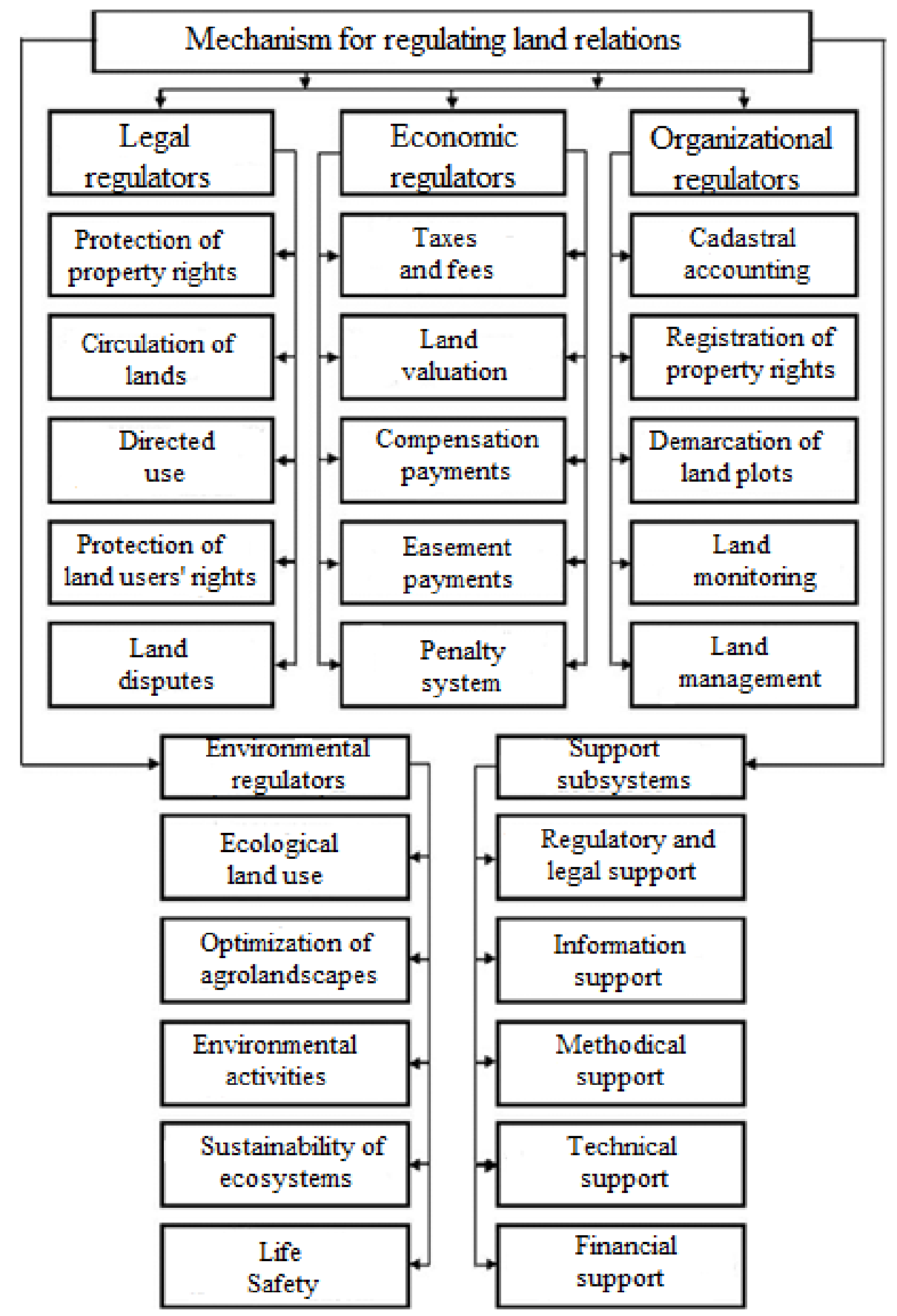

Fig. 1. Model of the mechanism of regulation of land relations 
The system of legal regulators is focused on the formation of the legal field, which allows to solve the problem of protecting the rights of landowners and the interests of land users, resolving land disputes, ensuring openness and legality of land turnover, their targeted and rational use.

The main tasks of the system of economic regulators are related to optimizing the amount of land tax and land turnover tax, regulating the market, cadastral and mortgage land prices of different quality and rent for land use, establishing the economically justified and socially fair level of compensation payments and easements, reasonable amounts of fines for violation of land use rules and environmental damage and incentive payments related to increasing soil fertility, quality of agricultural landscapes, etc.

One of the key elements of the land regulation mechanism is a system of organizational regulators that ensure the implementation of such tasks as land cadastre, registration of property rights, land surveying, land use monitoring, land management, and land use organization. The efficiency of all other elements of the mechanism depends on the quality and functional completeness of this system.

Since land is a natural object and is a spatial and productive basis of agriculture, a special role in the mechanism of land relations is given to the system of environmental regulators that shape the conditions of greening and biologization of land use, optimization of agricultural landscapes, environmental protection, sustainable ecosystems. ensuring the safety of life of the rural population.

The effectiveness of the mechanism for regulating land relations is largely determined by the quality and level of development of subsystems (regulatory, informational, methodological, technical, and financial support) designed to create and maintain the environment necessary for the full application of legal, economic, organizational and environmental regulators.

In addition, it should be noted that the mechanism of regulation of land relations, being a relatively autonomous element of the organizational and economic mechanism of state management of land resources, provides a clear division of regulatory functions and tasks between governments at all levels according to their powers and competence. 
A study of the system of economic regulators has shown that they are currently in the process of formation, which is characterized by an insufficient level of elaboration of their methodological support, including the determination of fees for productive land, as well as the agricultural purpose and an effective tool for protecting the economic interests of landowners and land users.

During the radical economic reforms of the end of the last century, the economic mechanism of the planned economy was dismantled, which provides for total regulation of all aspects of public life and the public nature of appropriation and redistribution of all types of income, including rents, seeking to form new mechanisms adapted to market economies. , new models of regulating the system of public relations were implemented in the development of the private property, competition, growing contradictions between different economic entities, a sharp weakening of the regulatory role of the state, frequent changes in agricultural and land policy, imperfect legal framework and others.

The revival of the institution of private property has objectively necessitated the solution of problems associated with encumbrances arising in respect of property, including land. In the general sense, such encumbrances are called easements, which represent the limited rights of some entities to use any property of other entities $[9,12]$.

In the current legislation on the objects of easement, there are land easements, water, forest easements, and easements of other real estates. A significant part of land easements arose in the pre-reform period in the conditions of the predominance of state ownership of land without registration of encumbrance agreements, as the state was both the owner of the land and the entity that initiates the establishment of the easement. Privatization of land through the granting of the right to land shares without the allocation of land in kind and the definition of their boundaries also did not contribute to the documentation of servitude relations. Given that the easement arises between the landowner and the entity in whose interests a particular easement was established, it becomes clear that a socially just system of easement payments can be formed only if there is a clear delineation of ownership of all encumbered land and recognition entities that have initiated the emergence of certain encumbrances and 
receive income from them, which can be used as a source of funding for the reproduction of productive lands.

The current level of development of servitude relations in Ukraine is characterized by a paradoxical situation: there are large-scale encumbrances on land plots (mainly related to construction, reconstruction and operation of linear facilities) involved in the agricultural production process, but easements are not established in the vast majority of cases. both due to the lack of delimitation of ownership of encumbered land, and due to the lack of mass practice of their establishment and the level of easement payments, the amount of which is lower than the costs associated with the registration of easements and keeping documents up to date.

Certain problems in rural areas for the use of land owned by citizens arise due to their small size and high density, which may also require the establishment of easements for the owner's access to their land, to ensure its operation per permitted uses and other needs of the owner, which can not be met without the establishment of an easement.

All land easements, according to the law, are divided into public and private. Private easements establish relations between citizens, as well as legal entities that own land plots that share common borders. In this case, the encumbrance is established following the agreement between the landowner and the entity initiating the easement, which fixes the conditions that determine the purpose and nature of the encumbrance, its term, the amount of easement payment, its implementation, etc. The emergence of this type of easement is for the private interests of individuals or legal entities. Public easements arise in the framework of the realization of public (public) interests associated with the realization of the mass needs of society in the country and local areas. They have established by-laws or other normative legal acts of subjects or bodies of local self-government.

The right to use the property of another entity objectively determines the need for payments to compensate the owner for losses arising from the establishment of an easement, which requires methods to assess the level of such losses or lost profits and determine the appropriate encumbrance value of a particular land. The socially fair 
value of encumbrance is a tool for balancing the interests of landowners and entities in whose interests a specific easement is established. Given the high importance of this instrument in developed countries, methods for determining the recommended amount of easement payments are developed and approved by the state, but can be revised by mutual consent of the subjects of easement or court decision taking into account the specifics of encumbrance. The determination of the total value of the encumbrance is usually the market or cadastral value of a particular land plot and the amount of lost profits of the landowner arising from the establishment of an easement, but other factors affecting the amount of easement may be taken into account. Also, when determining the proportionate compensation for encumbrances, the type of easement is often taken into account. When establishing private easements, the assessment may be carried out directly by agreement of the parties or during court proceedings. Under public easements, taking into account the purposes of their establishment and public importance, the amount of payments should be minimal, which does not harm the interests of land users.

Conclusion.It should be noted that the lost benefit in the system of agricultural production, due to the burden of productive land and limiting the possibilities of their production use, leads to redistribution of rental income in favor of other industries and spheres of social production, which significantly narrows landowners and land users. associated with the reproduction of land resources.

Additional problems in the formation and development of the servitude mechanism arise due to the incompleteness of land reforms, which provided for the transfer of most land to private ownership and the creation of a favorable environment for equal development of all forms of land ownership, provided a continuous delineation of rights to each land. Limited to the implementation of the political component of land reform (elimination of the state monopoly on land), the state did not create an effective mechanism for transforming land ownership into ownership of a particular land, did not ensure transparency in the lease of agricultural land in state, regional ownership. 
Remaining the largest landowner, the state does not initiate the processes of forming mechanisms for the official recognition of land encumbrances, the establishment of land easements and the introduction of mandatory easement payments. There are no uniform methods for determining the total compensation for the encumbrance of productive lands, which ensure the balance of interests of landowners and entities that initiate this encumbrance. The mechanisms of reinvestment of funds received by the state as the owner of land in the form of easement payments in the reproduction of land resources (most of the land used by agricultural organizations are in state and communal ownership and were provided to them on the rights of use or lease) are unfounded. There is no procedure for obtaining easement payments for encumbrances on land plots, the ownership of which is not delimited (land arrays, which are a set of land shares without allocating them in kind).

Suggestions.To form a mechanism for the formation and use of easement payments, and in general methods for determining the total compensation for the encumbrance of productive land, ensuring the balance of interests of landowners.

\section{References}

1. Bukhtoyarov, N.I (2017) Orhanizatsiyno-ekonomichnyy mekhanizm rehulyuvannya zemel'nykh vidnosyn $\mathrm{v}$ ahrarniy sferi [Organizational and economic mechanism of regulation of land relations in the agricultural sector]. Ekonomika Ukrayiny [Economy of Ukraine], 134-144. [in Ukrainian].

2. Bukhtoyarov, N.I. (2016) Do pytannya pro sutnist' mekhanizmu rehulyuvannya zemel'nykh vidnosyn [On the question of the essence of the mechanism of regulation of land relations]. Innovatsiyi $v$ APK: problemy ta perspektyvy [Innovations in agro-industrial complex: problems and prospects]. 30-39. [in Ukrainian].

3. Volkova, T.V. (2017) Zemel'na polityka: ponyattya ta osnovni oznaky [Land policy: concepts and main features] Pravova polityka ta pravove zhyttya [Legal policy and legal life]. 59-64. [in Ukrainian]. 
4. Halynovs'kyy, E.A. (2009) Teoretychni ta metodolohichni problemy zemel'nykh pravovidnosyn [Theoretical and methodological problems of land relations]. 320. [in Ukrainian].

5. Demydov, P.V. (2018) Stratehichne upravlinnya zemlyamy sil's'kohospodars'koho pryznachennya: sutnist', pryntsypy ta otsinka efektyvnosti [Strategic management of agricultural lands: essence, principles and evaluation of efficiency] Visnyk Khersons'koho derzhavnoho ahrarnoho universytetu [ Bulletin of Kherson State Agrarian University]. 2 (57), 237-247. [in Ukrainian].

6. Duhina, T.A. (2014) Rozvytok zemel'nykh vidnosyn v sil's'komu hospodarstvi Ukrayiny [Development of land relations in agriculture of Ukraine ] Ekonomika APK [Economics of agro-industrial complex], 2 (248), 78-85. [in Ukrainian].

7. Leppke, O.B. (2012) Orhanizatsiyno-ekonomichni ta pravovi aspekty rozvytku i rehulyuvannya zemel'no-servitutnykh vidnosyn v sil's'kohospodars'komu zemlekorystuvanni [Organizational-economic and legal aspects of development and regulation of land-servitude relations in agricultural land use ] Ekonomika. Pratsya. Upravlinnya $\mathrm{v}$ sil's'komu hospodarstvi [Economics. Work. Management in agriculture]. 4 (13), 6-12. [in Ukrainian].

8. Lipski, S.A. (2017) Do pytannya pro sutnist' i kharakter suchasnykh ahrarnozemel'nykh vidnosyn [On the question of the essence and nature of modern agrarianland relations] Pratsi Mykolayivs'koho derzhavnoho ahrarnoho universytetu [Proceedings of the Nikolaev State Agrarian University]. 68, 48-54. [in Ukrainian].

9. Mamontov, V.D., Sutyahin, B. Yu., Radyukova, Ya.Yu. (2015) Zemel'ni servituty: praktyka otsinky sumirnoyu platy [Land easements: the practice of estimating a reasonable fee] Formuvannya rynkovykh vidnosyn v Ukrayini [Formation of market relations in Ukraine]. 2 (142), 46-54. [in Ukrainian].

10. Pashuta, A.O. (2015) Stratehichni napryamy vdoskonalennya systemy zemel'nykh vidnosyn [Strategic directions of improving the system of land relation] Suchasna ekonomika: problemy i rishennya [Modern economy: problems and solutions]. 5 (65), 105-112. [in Ukrainian]. 
11. Severyna, Yu.N. (2017) Osoblyvosti ahroprodovol'choho kompleksu yak ob'yekta upravlinnya [Features of agro-food complex as an object of management] Formuvannya rynkovykh vidnosyn $\mathrm{v}$ Ukrayini [Formation of market relations in Ukraine ]9, 54-61. [in Ukrainian].

12. (2016) Servitutni vidnosyny v Ukrayini [Easement relations in Ukraine ] Ahrarna osvita i nauka [Agrarian education and science]. 2016. 4, 22.

13. Ulez'ko, A.V. (2015) Osoblyvosti orhanizatsiyi innovatsiynykh protsesiv v ahroprodovol'chomu kompleksi [Peculiarities of organization of innovation processes in agro-food complex ] Ekonomika Ukrayiny [Economy of Ukraine]. 4 (47), 218-227. [in Ukrainian].

\section{Мовчан С.І., Якунічева А.Ю., Леженкін І.О., Коломісць С.М. ТЕОРЕТИЧНІ АСПЕКТИ ФОРМУВАННЯ МЕХАНІЗМУ} РЕГУЛЮВАННЯ ЗЕМЕЛЬНИХ ВІДНОСИН

Досліджується зміст економічної категорії «земельні відносини»; розкриваються чинники, що обумовлюють особливості земельних відносин в аграрній сфері $i$ їх регулювання; описується модель механізму регулювання земельних відносин, яку представляють у вигляді сукупності структурнофункиіональних елементів (системи правових, економічних, організаційних та екологічних регуляторів і підсистем нормативно-правового, інформаційного, методичного, технічного та фінансового забезпечення), щэо дозволяють за допомогою використання спеціальних методів та інструментів впливати на суб'єкти земельних відносин в рамках реалізачії земельної політики держави для досягнення иілей державного управління земельними відносинами; відзначається парадоксальність ситуачії, пов'язаної з наявністю масштабних обтяжень земельних ділянок, залучених до прочесу сільськогосподарського виробництва, але відсутністю встановлених сервітутів як в силу нерозмежованості власності на обтяжені земельні ділянки, так $і$ в силу відсутності масової практики їх встановлення; виявлено специфіку земельних сервітутів в сільському господарстві, щэо має вигляд, по-перше, в тому, що значна їх частина 
виникла в дореформений період в умовах переважання державної власності на землю без оформлення договорів обтяження; по-друге, через низьку активність держави в ініиіачії прочесів формування механізмів офіиійного визнання обтяження земель, встановлення земельних сервітутів та введення обов'язковості сервітутних платежів; по-третє, у відсутності єдиних методик визначення сумірною компенсації за обтяження продуктивних земель; по-четверте, у відсутності механізмів реінвестування коштів, отриманих власниками землі в вигляді сервітутних платежів, в відтворення земельних ресурсів; в- п'ятих, у відсутності механізмів отримання сервітутних платежів за обтяження земельних ділянок, власність на які не розмежована.

Ключові слова: земельні відносини, земельні ресурси, механізм регулювання, земельний сервітут, сервітутні відносини.

Мовчан С.И., Якуничева А.Ю., Леженкин И.А., Коломиец С.М. ТЕОРЕТИЧЕСКИЕ ОСОБЕННОСТИ ФОРМИРОВАНИЯ МЕХАНИЗМА РЕГУЛИРОВАНИЯ ЗЕМЕЛЬНЫХ ОТНОШЕНИЙ

Исследуется содержание экономической категории «земельных отношений»; изучаются факторы, которые определяют особенности земельных отношений в сельском хозяйстве и устанавливают принципы их регулирования; предлагается модель, основанная на механизме регулирования земельных отношений, в виде совокупности функциональных элементов (системы экономических, правовых, организационных и экологических регуляторов и подсистем обеспечения менеджемента), специальные методы и инструменты влияют на субъекты земельных отношений и являются частью земельной политики государства для управления земельными отношениями; выявляется несогласованность ситуации, которая связана с масштабными обременениями земель, вовлеченных в аграрный сектор, и одновременным отсутствием сервитутов.Описанная проблема возникла как из-за неограниченности прав собственности на обремененные земельные участки, так и из-за редкости их установки; нами была выявлена специфика земельных сервитутов в аграрном 
секторе, которая в свою очередь подтверждает, что наибольшая их часть возникла в условиях преобладания государственной собственности на землю, когда не оформлялись договора обременения и в условиях отсутствия активности со строны государства для формирования механизмов признания обременения земель в законодательном поле; в условиях установления земельных сервитутов и введении обязательности сервитутных платежей; при отсутствии единых методик определения соразмерной компенсации за обременения продуктивных земель; также из-за непродуманности механизмов реинвестирования средств, полученных владельцами земли в виде сервитутных платежей, в воспроизводства земельных ресурсов; в условиях отсутствия механизмов получения сервитутных платежей за обременения земельных участков, собственность на которые не разграничена.

Ключевые слова: земельные отношения, земельные ресурсы, механизм регулирования, земельный сервитут, сервитутные отношения. 